\title{
The Impact of Transformational Leadership Style on Organizational Performance: Evidence from Jordan
}

\author{
Tareq Ghaleb Abu Orabi \\ Assistant Professor, Department of Business, Albalqa Applied University \\ P.O. Box 1705, Amman 11118, Jordan \\ Email: Tareq_abuorabi@yahoo.com
}

Received: April 10, 2016 Accepted: April 26, 2016 Published: May 21, 2016

doi:10.5296/ijhrs.v6i2.9427 URL: http://dx.doi.org/10.5296/ijhrs.v6i2.9427

\begin{abstract}
Transformational leadership has garnered considerable attention in the literature because of its potential implications for the performance of the organization. Research indicates that this type of leadership can collectively impact employee behavior and commitment leading to improvements in the work climate and knowledge sharing. When combined, these changes can positively influence the performance of the organization. Using this as a foundation for investigation the current research considers the role of transformational leadership and its four components - idealized influence, inspirational motivation, intellectual stimulation, and individual consideration - and their influence on organizational performance in three banks operating in Jordan. A total of 249 surveys were distributed with 213 retuned and 171 eligible for use. The data was analyzed using multiple regression with a significance level of $\mathrm{p}<0.05$. The results indicate that while transformational leadership and three of its components-inspirational motivation, intellectual stimulation, and individual consideration - did contribute to 81.6 percent of the variance in organizational performance; idealized influence was not a significant factor contributing to this outcome. Leaders may need to focus on these elements of transformational leadership to improve outcomes for organizational performance.
\end{abstract}

Keywords: Transformational leadership, Idealized influence, Inspirational motivation, Intellectual stimulation, Individual consideration, Organizational performance 


\section{Introduction}

Research regarding the topic of organizational performance suggests that this variable is one of the most important for leaders to consider when attempting to build and improve their operations (Kroll, 2016). Despite the importance of organizational performance few investigators have sought to understand what facilities desired outcomes when it comes to performance (Kroll, 2016). Leadership offered within the organization has been targeted as a potential area for enhancing organizational performance (Overall, 2015). In particular transformational leadership has been identified as a "refreshingly different" approach to supporting employees; one that has the potential to markedly revolutionize organizational performance (Pradhan \& Pradhan, 2015, p. 228). As the business environment in Jordan becomes more complex as a result of market competition, globalization, technology, and intensified customer demands (Al-Mawali, 2013) organizations must cultivate the supports needed to achieve desired performance results.

\section{Literature Review}

\subsection{Definitions of Transformational Leadership}

General information regarding the definition of leadership indicates that this process involves the ability of one individual to motivate and influence others (de Oliveira Rodriguez \& Ferreira, 2015). Ideally motivation and influence occur in a manner that is positive and respectful, contributing to the achievement of specific goals (de Oliveira Rodriguez \& Ferreira, 2015). While this basic definition of leadership has consistently been used as a foundation for evaluating this process, scholars have developed various frameworks aimed at understanding the theoretical foundations of leadership in practice (Ghasabeh, Reaiche, \& Sossay, 2015). Trait, behavioral, situational, transactional, and transformational leadership styles are just a few of the theories that have been proposed to evaluate the rudiments of leader behavior and the basis for motivation and influence (Ghasabeh et al., 2015).

Even though an understanding of the continuum of leadership theories provides insight into the evolution that has occurred in this field, an examination of transformational leadership and its definition does provide a culminating description of efforts made to study leadership practice. As described by Ghasabeh et al. (2015) transformational leadership focuses on satisfying the basic and higher-order needs of followers through inspiration to achieved desired goals. Transformational leadership is often juxtaposed against transactional leadership in which transactions form the basis of follower motivation (Kim \& Yoon, 2015). Transformational leadership differs in that it creates a deep internal desire for motivation that is not sustained through transactions; rather motivation for the follower is sustained through true inspiration or transformation in the desire to achieve goals (Kim \& Yoon, 2015).

\subsection{Characteristics of Transformational Leadership}

Although the basic definition of transformational leadership provided above facilitates comprehension of the process and how transformational leadership differs from other types of leadership practice, a review of what has been noted about this paradigm clearly indicates that there are specific mechanisms through which transformational leadership operates to 
provide motivation for the follower. Specifically, research indicates that transformational leadership is comprised of the "Four I's" including: idealized influence, inspirational motivation, intellectual simulation, and individualized consideration (Tharnpas \& Boon-itt, 2015). Each of these elements contributes to the transformational process through which effective and positive leadership is achieved (Caillier, 2014).

Information regarding the role and function of each of the Four I's indicates that specific elements of follower development are cultivated in order to create a holistic foundation for leadership practice (Caillier, 2014). Idealized influence involves the ability of leaders to inspire followers to achieve a specific goal with additional personal effort while inspirational motivation involves the development of a vision and positive expectations that followers can accomplish (Verissimo \& Lacerda, 2015). Intellectual stimulation results when leaders develop the capacity of followers to solve problems through creativity and innovation while individualized consideration requires leaders to recognize and support the contributions of each follower to goal achievement (Verissimo \& Lacerda, 2015). Each of these elements works in combination to facilitate the motivation of the employee on a deeper level indicating a high level of inspiration (Tharnpas \& Boon-itt, 2015; Verissimo \& Lacerda, 2015).

\subsection{Transformational Leadership and Organizational Performance}

Data provided regarding the impact of transformational leadership clearly indicates that this approach has notable implications for followers. Collectively the transformation of employees should have direct implications for organizational performance (Hoxha, 2015). Trmal, Bustamam, and Mohamed (2015) substantiate this assertion by noting that transformational leadership is effective because it drives changes in individual behavior which leads to the achievement of organizational goals. As a result transformational leadership has the potential to have a substantial impact on the overall performance of the organization, creating the supports needed to ensure that desired outcomes for operations result.

\section{Theoretical Framework}

A review of the literature does indicate that transformational leadership can have a positive impact on the overall performance of the organization. Based on this assertion and an understanding of the four central components of transformational leadership, a theoretical framework to understand how transformational leadership influences organizational performance was formulated. The framework proposes the use of five independent variables including: transformational leadership, idealized influence, inspirational motivation, intellectual stimulation, and individual consideration. Organizational performance as measured through effectiveness and efficiency was utilized as the dependent variable. The framework proposes that while transformational leadership may result in the development of improved organizational performance, specific elements of transformational leadership may play are more significant or substantial role in shaping performance outcomes.

\subsection{Relationship: Transformational Leadership and Performance}

The relationship between transformational leadership and organizational performance was 
briefly examined in the introduction to this work. In an effort to understand the role that transformational leadership plays in the development of organizational performance, various scholars have considered how this leadership theory impacts specific aspects of employee and organizational behavior to shape outcomes. For instance, Choudhary, Akhtar, and Zaheer (2013) demonstrate the impact of transformational leadership on organizational learning, demonstrating that this approach can be used to improve the ability of the organization to change and innovate. This can prompt growth and expansion indicating successful organizational performance (Choudhary et al., 2013).

Transformational leadership was also found by De Jong and Bruch (2013) to have a direct impact on organizational climate. De Jong and Bruch argue that through transformational leadership the climate of the organization can be strengthened creating an environment in which employees are motivated and energized. This facilitates the achievement of organizational goals and hence increased performance (De Jong \& Bruch, 2013). Giroux and McLarney (2014) provide an expanded evaluation of the impact of transformational leadership on climate noting that this outcome has systemic implications for employees, customers, and shareholders. Motivated employees working in a supportive climate provide more effective customer service, bolstering organizational performance and leading to financial gains for shareholders (Giroux \& McLarney, 2014).

\subsection{Relationship: Idealized Influence and Performance}

Idealized influence is one of the four components of transformational leadership identified as an independent variable for this investigation. Scholars examining this process assert that idealized influence refers to the idea that followers will trust and respect leaders to provide support and resources (Chu \& Lai, 2011). As a result of this belief, employees will be willing to accept the directives provided by the leader, regardless of their complexity or difficulty (Chu \& Lai, 2011). Although the role of idealized influence and its implications for organizational performance is often conceptualized as part of transformational leadership, there is evidence indicating that idealized influence may impact particular aspects of organizational performance. In particular, idealized influence may have implications for employee commitment and satisfaction to facilitate engagement and motivation while on the job (Chen, 2004). Understanding the specific impact of idealized influence on organizational performance is thus imperative for expanding comprehension of how transformational leadership influences organizational outcomes.

\subsection{Relationship: Inspirational Motivation and Performance}

Inspirational motivation is another component of transformational leadership that is examined in this investigation as an independent variable. Inspirational motivation is extensively reviewed by Doody and Doody (2012) who argue that the process involves encouraging followers to align personal goals with the goals of the organization. Through this process, Doody and Doody argue that the objectives of the organization are simultaneously achieved, with the outcomes having implications for both the employee and the organization. Much like the variable of idealized influence, inspirational motivation and its impact on organizational performance has not been widely examined outside of the context of transformational 


\section{Ml Macrothink}

International Journal of Human Resource Studies

ISSN 2162-3058 2016, Vol. 6, No. 2

leadership. Rawung, Wuryaningrat, and Elvinita (2015) consider the role of inspirational motivation noting its role in building trust and satisfaction for the employee. According to these authors, inspirational motivation can serves as the foundation for knowledge sharing; an important component of facilitating the success of the organization. The dearth of insight regarding the degree to which inspirational motivation influences outcomes for organizational performance prompts the need to examine this variable independently to garner a more precise understanding of its impact.

\subsection{Relationship: Intellectual Stimulation and Performance}

Intellectual stimulation represents an important component of transformational leadership and is also included as an independent variable for evaluation. A review of this variable suggests that intellectual stimulation facilitates follower empowerment through communication and encouragement to identify problems and solutions (Smothers, Doleh, Celuch, Peluchette, \& Valadares, 2016). The role of intellectual stimulation on organizational performance has been evaluated more extensively in the literature as an independent variable shaping outcomes for employees in the organization. In particular, Anjali and Anand (2015) assert that intellectual simulation leads to the development of employee commitment to the organization. This, in turn, has implications for the ability of the organization to achieve goals based on the dedication and hard work of employees (Anjali \& Anand, 2015).

\subsection{Relationship: Individual Consideration and Performance}

The final independent variable selected for review in this investigation is individual consideration. Zacher, Pearce, Rooney, and McKenna (2014) consider the scope if individual consideration noting that the process involves the willingness and ability of the leader to provide nurturing support for each follower. In terms of the implication of individual consideration for organizational performance, Snell, Stanley, Zhang, and Almaz (2013) argue that this process can positively influence employee job satisfaction, leading to higher levels of engagement and motivation within the organization. When all employees experience this outcome organizational performance should improve (Snell et al., 2013).

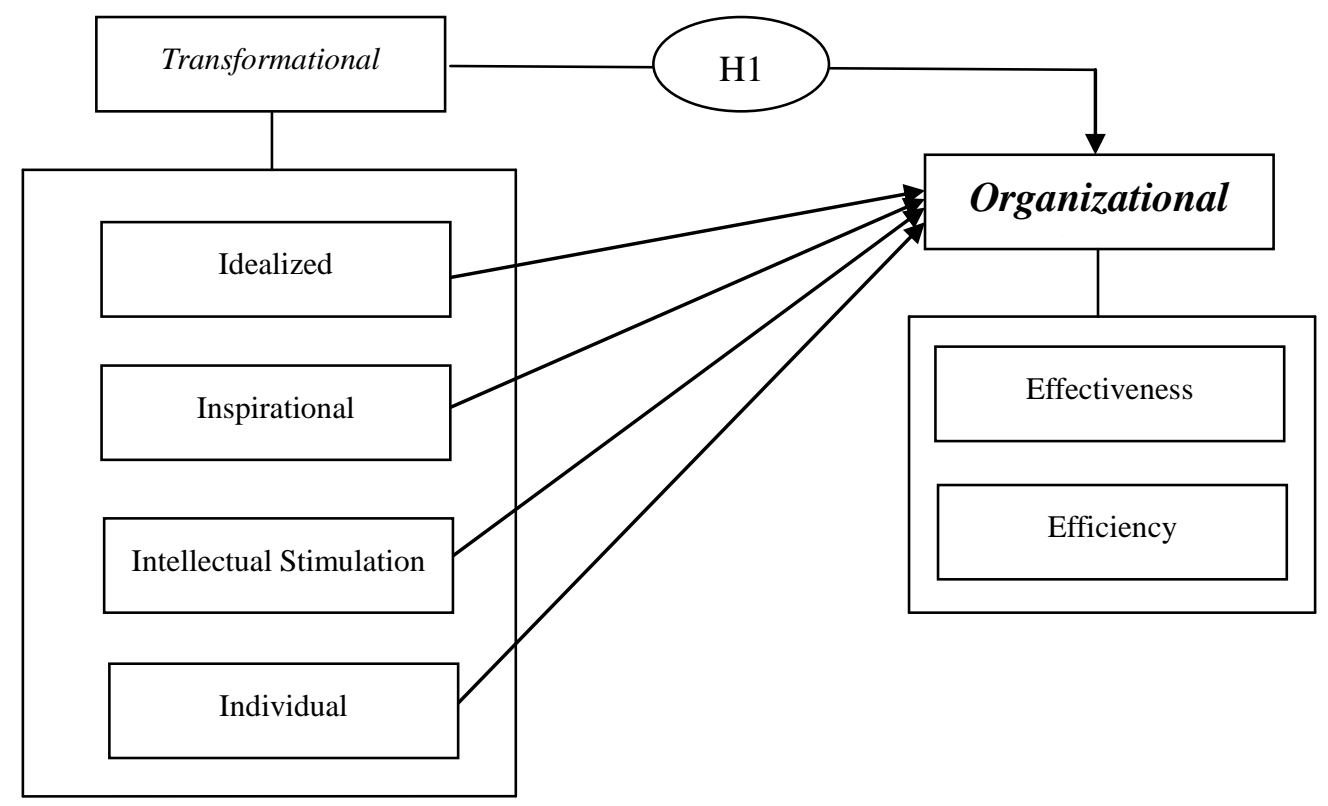




\subsection{Hypothesis of the Study}

The hypotheses of the study are proposed to test the propositions put forth as part of the theoretical model and are as follows:

H1: There a significant relationship between Transformational Leadership Styles and Organizational Performance.

$\mathrm{H} 2$ : There is a significant relationship between Idealized Influence and Organizational Performance.

H3: There is a significant relationship between Inspirational Motivation and Organizational Performance.

H4: There is a significant relationship between Intellectual Stimulation and Organizational Performance.

H5: There is a significant relationship between Individual consideration and Organizational Performance.

\section{Materials and Methods}

\subsection{Data Collection}

Data collection for this investigation involved the use of a questionnaire to measure both the performance of the organization in terms of efficiency and efficacy as well as dimensions of transformational leadership including: idealized influence, inspirational motivation, intellectual stimulation and individual consideration. The questionnaire was sent to three major banks currently operating in Jordan. Each of the banks had been contacted prior to sending the surveys to acquire permission for employees in the organization to participate in the study. Employees were given the option to voluntarily participate and to complete and return their surveys anonymously.

In total 249 surveys were distributed to the three banks. After two weeks 213 of the surveys had been collected and returned to the researcher. This indicates an 86 percent response rate. The high rate of response reduces the threat of non-response bias when analyzing the dat. A review of the returned surveys indicated that 171 were complete and valid for inclusion in the current study. This sample size produces a confidence interval of 6 at the 95 percent for a population with an unknown size. This indicates that the sample was adequate for testing the hypotheses of the study.

\subsection{Instrument}

The instrument used for this investigation included a survey designed specifically for use in this investigation. Questions regarding transformational leadership were modified from the Multifactor Leadership Questionnaire. A total of 19 questions were included on the instrument as follows: idealized influence (4 questions), inspirational motivation (3 questions), intellectual stimulation (3 questions), and individual considerations (3 questions). The instrument also included six questions regarding the performance of the organization. 


\section{Macrothink}

International Journal of Human Resource Studies

ISSN 2162-3058

2016, Vol. 6, No. 2

Employees completing the survey were asked to provide their perception of performance based on their knowledge and experiences.

All of the questions on the survey were rated on a five-point Likert scale ranging from $1=$ strongly disagree to $5=$ strongly agree. Higher scores on the scale were indicative of an increased presence of the variable within the organization. Higher scores were also indicative of higher levels of perception regarding the performance of the organization. Likert-scales are commonly used to provide standardized measures of participant opinions that allow for comparison across diverse populations (Groves, Fowler, \& Couper, 2011)

\section{Results and Discussion}

\subsection{Reliability Analysis}

Table 1: Reliability Analysis

\begin{tabular}{|l|l|l|}
\hline Contract & Number of items & Alpha coefficient \\
\hline $\begin{array}{l}\text { Idealized } \\
\text { Influence }\end{array}$ & 4 & .854 \\
\hline $\begin{array}{l}\text { Inspirational } \\
\text { Motivation }\end{array}$ & $\mathbf{3}$ & .913 \\
\hline $\begin{array}{l}\text { Intellectual } \\
\text { Stimulation }\end{array}$ & $\mathbf{3}$ & .901 \\
\hline $\begin{array}{l}\text { Individual } \\
\text { consideration }\end{array}$ & $\mathbf{3}$ & .911 \\
\hline $\begin{array}{l}\text { Organizational } \\
\text { Performance }\end{array}$ & 6 & .829 \\
\hline
\end{tabular}

Reliability analysis for this investigation was performed using each of the five items measured through the survey. Specifically, Cronbach's alpha was utilized to measure the degree to which the set of variables measures evaluates a specific latent construct (Andrew, Pedersen, \& McEvoy, 2011). Cronbach's alpha provides a correlation between the survey item and the construct that it intends to measure (Andrew et al., 2011). Cronbach's alpha values range between 0 and 1 with higher numbers indicating that correlations between a respective survey item and the construct it measures are reliable (Andrew et al., 2011). Cronbach's alpha levels above 0.7 are desirable indicating that the measured results are indeed representative of the construct being measured (Andrew et al., 2011).

Table 1 below provides an overview of the Cronbach's alpha measures that were tabulated for this investigation. The results indicate that all of the values are over the 0.70 threshold ranging between 0.829 for organizational performance and 0.913 for inspirational motivation. 


\section{Macrothink}

International Journal of Human Resource Studies

ISSN 2162-3058 2016, Vol. 6, No. 2

Based on the results, it is possible to argue that the instrument used for measuring each of this constructs provides reliable results, supporting the use of the instrument to acquire insight into each of the variables selected for investigation.

\subsection{Demographic Profile of Respondents}

Table 2: Demographic Characteristics of Respondents $(\mathrm{N}=171)$

\begin{tabular}{|c|c|c|}
\hline Variables & Percentages & Cumulative (\%) \\
\hline \multicolumn{3}{|l|}{ Gender } \\
\hline Male & 62.2 & 62.2 \\
\hline Female & 37.8 & 100 \\
\hline \multicolumn{3}{|l|}{ Age } \\
\hline$<31$ & 62.2 & 62.2 \\
\hline 31- 39 & 13.0 & 75.2 \\
\hline $40-49$ & 21.7 & 97.0 \\
\hline $50-59$ & 3.0 & 100 \\
\hline \multicolumn{3}{|l|}{ Education level } \\
\hline Diploma & 28.3 & 28.3 \\
\hline Bachelor & 70 & 98.3 \\
\hline Postgraduate & 1.7 & 100 \\
\hline \multicolumn{3}{|l|}{ Position } \\
\hline Employee & 46.1 & 46.1 \\
\hline Manager & 38.3 & 84.4 \\
\hline Supervisor & 11.6 & 96 \\
\hline Executive & 4 & 100 \\
\hline
\end{tabular}

A summary of the demographic profile of respondents for the survey is provided below in Table 2. The results indicate that males (62.2 percent) represented the majority of respondents. Females comprised only 37.8 percent of participants. Data also indicates that a majority of the respondents were under the age of 31 (62.2 percent). The second largest age group to complete the survey included those between the ages of 40 and 49 (21.7 percent) followed by those between the ages of 31 and 39 (13.0 percent) and those between the ages of 50 and 59 (3.0 percent). A majority of the respondents (70 percent) reporting having a Bachelor's 


\section{Macrothink}

International Journal of Human Resource Studies

ISSN 2162-3058 2016, Vol. 6, No. 2

Degree with 29.3 percent reporting having a diploma and 1.7 percent reporting completing postgraduate education. Demographic information collected also included the position of the respondent in the organization. Table 3 demonstrates that of those completing the survey 46.1 percent were employees, 38.3 percent were managers, 11.6 percent were supervisors, and 4.0 percent were executives.

\subsection{Hypothesis Testing}

Hypothesis testing was undertaken utilizing multiple regression analysis. Specifically, this data analysis tool was utilized to evaluate the four dimensions of transformational leadership-idealized influence, inspirational motivation, intellectual stimulation, and individual consideration - in conjunction with the dependent variable of organizational performance. The level of significance for each of the variables was measured at the $p<0.05$ level. Standardized $\beta$ coefficients were also tabulated with positive numbers indicating that the result had a positive influence on the development of organizational performance. Table 3 below provides an overview of the results of the multiple regression analysis.

Table 4: Results of Multiple Regression Analysis

\begin{tabular}{|l|l|l|l|}
\hline Model & $\begin{array}{l}\text { Standardized } \\
\text { Coefficient }(\beta)\end{array}$ & t-value & Sig. \\
\hline Idealized Influence & .269 & 1.837 & .068 \\
\hline $\begin{array}{l}\text { Inspirational } \\
\text { Motivation }\end{array}$ & .160 & 2.466 & .000 \\
\hline $\begin{array}{l}\text { Intellectual } \\
\text { Stimulation }\end{array}$ & .365 & 5.433 & .000 \\
\hline $\begin{array}{l}\text { Individual } \\
\text { consideration }\end{array}$ & .211 & 4.178 & .000 \\
\hline
\end{tabular}

$\mathrm{R} 2=.816 ; \quad$ Adjusted $\mathrm{R} 2=.779 ; \quad$ F-value $=49.8 ; \quad$ Significance $=0.00$

The results indicate that inspirational motivation, intellectual stimulation, and individual consideration have a statistically significant $(\mathrm{p}=0.00)$ and positive influence on organizational performance ( $\beta$ coefficients). However, the results also indicate that idealized influence does not have a significant influence over organizational performance $(p=0.068)$. This outcome will have implications for understanding the impact of transformational leadership on organizational performance, requiring efforts to better understand the role of idealized influence in transformational leadership in general. 
The regression analysis also indicates that intellectual stimulation played the most significant role in shaping outcomes for organizational performance with individual consideration having the second most prominent influence. The $\mathrm{R} 2$ value of .816 further indicates that the statistically relevant variables account for 81.6 percent of the total variance in organizational performance. The results therefore allow for accepting hypotheses 1, 3, 4, and 5. However, it is important to consider the results as they relate to the specific issue of idealized influence as this hypothesis (2) could not be supported from this data.

\section{Discussion}

As noted the results provided in this investigation do not support hypothesis 2 but do support all of the other hypotheses proposed for this investigation. Table 5 includes a review of the hypotheses developed for this investigation with a review of the results as they relate to the data analysis conducted for this investigation.

Table 6: Summary of Results in Relation to Research Hypotheses

\begin{tabular}{|l|l|l|}
\hline No. & Hypothesis & Finding \\
\hline H1: & $\begin{array}{l}\text { There a significant relationship between Transformational } \\
\text { Leadership Styles and Organizational Performance. }\end{array}$ & Supported \\
\hline H2: & $\begin{array}{l}\text { There is a significant relationship between Idealized Influence } \\
\text { and Organizational Performance. }\end{array}$ & Not Supported \\
\hline H3: & $\begin{array}{l}\text { There is a significant relationship between Inspirational } \\
\text { Motivation and Organizational Performance. }\end{array}$ & Supported \\
\hline H4: & $\begin{array}{l}\text { There is a significant relationship between Intellectual } \\
\text { Stimulation and Organizational Performance. }\end{array}$ & Supported \\
\hline H5: & $\begin{array}{l}\text { There is a significant relationship between Individual } \\
\text { consideration and Organizational Performance. }\end{array}$ & Supported \\
\hline
\end{tabular}

With respect to the first hypothesis proposed for this investigation - that transformational leadership has a significant relationship with organizational performance - the results from this investigation appear to be commensurate with data collected from previous studies (Hoxha, 2015; Trmal et al., 2015; Choudhary et al., 2013). In general, transformational leadership appears to have the ability to support employees such that they are more committed, more engaged and more satisfied with their work (Hoxha, 2015). This has been shown to lead to a wide range of outcomes including increased creativity, problem solving, and innovation (DeJong \& Bruch, 2013). Transformational leadership improves the climate of the organization resulting in positive influences on employee behavior that have direct and measurable outcomes for organizational performance (Giroux \& McLarney, 2014). 
Although the role of transformational leaders is supported in the context of improving organizational performance, one of the central components of the paradigm did not prove to have a salient impact on organizational performance in this research. In particular, hypothesis 2 was not supported with the results indicating that idealized influence did not have a significant impact on organizational performance. This issue is one of notable concern given that idealized influence is one only four constructs that comprise transformational leadership (Tharnpas \& Boon-itt, 2015). Understanding why idealized influence does not impact organizational performance requires a broader examination about what has been noted about this construct in the literature.

Idealized influence involves the ability of leaders to inspire followers to align personal and organizational goals to achieve positive outcomes simultaneously (Caillier, 2014). As noted earlier in this investigation idealized influence and its implications for organizational performance have not been widely examined in the literature. However there is evidence which suggests that idealized influence impacts employee commitment and job satisfaction (Chen, 2004). When these findings are juxtaposed against research regarding the role of inspirational motivation, intellectual stimulation, and individual consideration it becomes evident that these variables have similar outcomes for employees and organizational performance (Rawung et al., 2015; Anjali \& Anand, 2015; Snell et al., 2013). As such it is possible that the effects of inspirational motivation, intellectual stimulation, and individual consideration combined have significant influence, minimizing the role of idealized influence in shaping outcomes.

Interesting, the variable found to have the most influence on organizational performance - intellectual simulation - has been extensively noted as an independent variable impacting organizational performance (Snell et al., 2013). Clearly, each of the Four I's contributes to similar outcomes with regarding to employee commitment and satisfaction. However it is evident that when these Four I's are compared there are differences in the degree to which each impacts organizational performance. Understanding these differences should provide a foundation for developing transformational leadership in practice. Based on the results obtained from this investigation it is evident that leaders employing this approach should focus on intellectual stimulation and individual consideration to bolster organizational performance.

\section{Limitations and Future Research}

Although the current investigation provides preliminary insight into the role of transformational leadership in influencing organizational performance, the study is limited by the scope and size of the sample. The research focuses specifically on the banking sector in Jordan with only three banks and 171 employees surveyed. Future research should include a larger sample size as well as a consideration of different industries. Comparison of results from different occupations may provide insight into whether or not transformational leadership has different impacts for employees working in diverse fields. 


\section{Conclusion}

The results of this investigation do support the use of transformational leadership to positively influence organizational performance. Even though this model of leadership practice can be important for shaping outcomes for performance, specific elements of the model - intellectual stimulation and individual consideration - appear to play a substantial role in shaping outcomes. With these issues in mind, leaders utilizing transformational leadership should consider these areas for follower development as a means to augment the performance of the organization.

\section{References}

Al-Mawali, H. (2013). Performance consequence of management account system information usage in Jordan. Business \& Economic Horizons, 9(1), 22-31. doi: 10.15208/beh.2013.3

Andrew, D.P.S., Pedersen, P.M., \& McEvoy, C.D. (2011). Research methods and design in sport management. Champaign, IL: Human Kinetics.

Anjali, K.T., \& Anand, D. (2015). Intellectual stimulation and job commitment: A study of IT professionals. IUP Journal of Organizational Behavior, 14(2), 28-41 http://www.iupindia.in/Organizational_Behavior.asp

Caillier, J.G. (2014). Toward a better understanding of the relationship between transformational leadership, public service motivation, mission valence, and employee performance: A pilot study. Pubic Personnel Management, 43(2), 218-239. doi: $10.1177 / 0091026014528478$

Chen, L.Y. (2004). Examining the effect of organization culture and leadership behaviors on organizational commitment, job satisfaction, and job performance at small and middle-size firms in Taiwan. Journal of the American Academy of Business, Cambridge, 5(1/2), 432-438. http://www.jaabc.com/journal.htm

Choudhary, A., Akhtar, S., \& Zaheer, A. (2013). Impact of transformational and servant leadership on organizational performance: A comparative analysis. Journal of Business Ethics, 116(2), 433-440. doi: 10.1007/s10551-012-1470-8

Chu, L., \& Lai, C. (2011). A research on the influence of leadership style and job characteristics on job performance among accountants of county and city government in Taiwan. Public Personnel Management, 40(2), 101-118. doi: 10.1177/009102601104000202

De Jong, S.B., \& Bruch, H. (2013). The importance of a homogeneous transformational leadership climate for organizational performance. International Journal of Leadership Studies, 8(1), http://www.regent.edu/acad/global/publications/ijls/new/home.htm

De Oliveira Rodriguez, A., \& Ferreira, M.C. (2015). The impact of transactional and transformational leadership style on organizational citizenship behaviors. Psico-USF, 20(3), 493-504. doi: 10.1590/1413-8271201520031 
Doody, O., \& Doody, C.M. (2012). Transformational leadership in nursing practice. British Journal of Nursing, 21(20), 1212-1218. http://info.britishjournalofnursing.com/

Ghasabeh, M.S., Reaiche, C., \& Soosay, C. (2015). The emerging role of transformational leadership. Journal of Developing Areas, 49(6), 459-467. https://muse.jhu.edu/journals/journal_of_developing_areas/

Giroux, T., \& McLarney, C. (2014). Exploring the leadership continuum: The relevance of transformational leadership on organizational performance. Proceedings of the Northeast Region Decision Sciences Institute, 862-886. http://nedsi.org/

Groves, R.M., Fowler, F.J., \& Couper, M.P. (2011). Survey methodology (2nd ed.). Hoboken, NJ: John Wiley \& Sons.

Hoxha, A. (2015). Empowerment and trust as mediators of the relationship between transformational leadership and organizational effectiveness. European Journal of Economic \& Political Studies, 8(1), 43-60. http://www.ejeps.com/index.php/ejeps

Kim, S., \& Yoon, G. (2015). An innovation-driven culture in local government: Do senior manager's transformational leadership and the climate for creativity matter? Public Personnel Management, 44(2), 147-168. doi: 10.1177/0091026014568896

Kroll, A. (2016). Exploring the link between performance information use and organizational performance: A contingency approach. Public Performance \& Management Review, 39(1), 7-32. doi: 10.1080/15309576.2016.1071159

Overall, J. (2015). A conceptual framework of innovation and performance: The importance of leadership, relationship quality, and knowledge management. Academy of Entrepreneurship Journal, $21(2), \quad$ 41-54. http://www.alliedacademies.org/academy-of-entrepreneurship-journal/

Pradhan, S., \& Pradhan, R.K. (2015). Transformational leadership, affective organizational commitment and contextual performance. Vision, 19(3), 227-235. doi: $10.1177 / 097226291559708$

Rawung, F.H., Wuryaningrat, N.F., \& Elvinita, L.E. (2015). The influence of transformational and transactional leadership on knowledge sharing: An empirical study on small and medium business in Indonesia. Asian Academy of Management, 20(1), 123-145. http://web.usm.my/aamj/

Smothers, K., Doleh, R., Celuch, K., Peluchette, J., \& Valadares, K. (2016). Talk nerdy to me: The role of intellectual stimulation in the supervisor-employee relationship. Journal of Health \& Human Services Administration, 38(4), 478-508. http://www.spaef.com/jhhsa.php

Snell, R.S., Yi, Z., \& Chak, A.M.K. (2013). Representational predicaments for employees: Their impact on perceptions of supervisors' individualized consideration and on employee job satisfaction. International Journal of Human Resource Management, 24(8), 1646-1670. doi: 10.1080/09585192.2012.723634 


\section{Macrothink}

Tharnpas, S., \& Boon-itt, S. (2015). A study of CEO transformational leadership, organizational factors and product innovation performance: Scale development and a theoretical framework. International Journal of Innovation Science, 7(2), 107-125. doi: 10.1260/1757-2223.7.2.107

Trmal, S.A., Bustamam, U.S.A., \& Mohamed, Z.A. (2015). The effect of transformational leadership in achieving high performance workforce that exceeds organizational expectation: A study from a global and Islamic perspective. Global Business \& Management Research, 7(2), 88-94. http://www.gbmr.ioksp.com/

Verissimo, J.M.C., \& Lacerda, T.M.C. (2015). Does integrity matter for CSR practice in organizations? The mediating role of transformational leadership. Business Ethics: A European Review, 24(1), 34-51. doi: 10.1111/beer.12065

Zacher, H., Pearce, L., Rooney, D., \& McKenna, B. (2014). Leaders' personal wisdom and leader-member exchange quality: The role of individualized consideration. Journal of Business Ethics, 121(2), 171-187. doi: 10.1007/s10551-013-1692-4

\section{Copyright Disclaimer}

Copyright for this article is retained by the author(s), with first publication rights granted to the journal.

This is an open-access article distributed under the terms and conditions of the Creative Commons Attribution license (http://creativecommons.org/licenses/by/3.0/). 